\title{
Farmers' Pest Management Practices of Stored Faba Bean and their Implication to Food Security in Farta District, North West Ethiopia
}

\author{
Wondale Endshaw ${ }^{1, a}$, Berhanu Hiruy ${ }^{1, b, *}$ \\ ${ }^{1}$ Department of Biology, College of Natural Sciences, Arba Minch University, Arba Minch, Ethiopia \\ *Corresponding author
}

\section{A R T I C L E I N F O A B S T R A C T}

Research Article

Faba bean is the most important legume grown in Ethiopia. But, insect pests have been causing its substantial loss under farmers' storages. A survey to assess the farmers' pest protection practices of stored faba bean was conducted in its selected major growing peasant associations of the Farta District from 4 January 2019 - 15 May 2020. Semi-structured questionnaires and farmers'

Received : 02/09/2020

Accepted : 22/10/2020 participatory discussion were used to conduct the study. Accordingly, the majority of farmers $(66.7 \%)$ harvested their grain in usual time (in December) fearing insect pests infestation. A substantial proportion of the farmers $(25 \%)$ used a combination of cultural and botanical methods, followed by botanicals $(20.83 \%$ ) for grains protection. Eucalyptus globlus, Croton macrostachyus and Otostegia tomentosa were the three most commonly used botanicals and suggested to be potent.

Keywords:

Infestation level Insect pests

Management practices

Stored faba bean

Traditional practices Threshing was done most commonly by livestock $(66.7 \%)$, followed by beating with sticks $(25 \%)$ both of which are not recommended as they might lead to grain losses. The insect infestation level was high in threshed and un-threshed forms of faba beans after 3 and 7 months storage periods, respectively. Consequently, the farmers' traditional practices were ineffectual for storing beans for longer periods. Therefore, planning pest management strategies of stored beans are desirable.

\section{Introduction}

Pulses are a vital source of diet for billions of people worldwide. The term pulses have been interchangeably used with the term legumes, as all pulses has been considered legumes, but not all legumes are considered pulses (Singh, 2017). Pulses are defined as dry harvested seeds, which include several varieties that are different from leguminous oil seeds by their low fat content (Marinangeli et al., 2017; Getachew, 2019). They do not consist of legumes that have high levels of fat or oil and/or moisture at the time of the harvest, such as soybeans, peanuts, fresh peas, among others (Marinangeli et al., 2017). Accordingly, they belong to the family leguminoseae and comprise those types of legumes that are consumed by human beings and domestic animals, usually as dry grains. And they do not include those legumes which are grown mainly for edible oil such as ground nuts along with the aforementioned ones (Singh, 2017).

Pulses could subsidize the smallholder income, as well as diet, as it is a greater price crop than cereals, and as it is a cost-effective source of protein, respectively (Yirga et al., 2010; Getachew, 2019). They are considered as poor man's meat, as they are importantly a chief an inexpensive source of protein (20-35\%, on average) and essential amino acids (Koroma et al., 2016). They are also a critical and inexpensive source of plant-based carbohydrates, vitamins, and minerals for people around the globe (FAO, 2016). In other words, they are also a rich source of carbohydrates (about 60\%), vitamins (folate, thiamin, riboflavin, niacin, and pyridoxine), a range of minerals (zinc, potassium, iron, calcium, magnesium, and selenium) (Szczebyło et al., 2020) and micronutrients (Koroma et al., 2016). In protein, pulses are particularly rich in the amino acid lysine, which is often low in cereals (Szczebyło et al., 2020). They also represent good sources of additional protein, when used along cereals and root produces, which are low in essential amino acids, for of their great lysine and protein contents (Koroma et al., 2016). They also hold zero cholesterol, a small fat content, and are a significant source of dietary fiber, and hence, they contribute to combating obesity. Furthermore, they have no gluten, besides to the aforementioned important values, all of which make fit it for a healthy life (FAO, 2016). 
Pulses also offer safe soil preservation profits through fixing nitrogen, which increases the yields of cereals via the rotation of crops (Yirga et al., 2010; FAO, 2016; Getachew, 2019; Kebede, 2019). As a result, from an agricultural point of view, multiple cropping systems that include pulses enhance soil fertility, improve yields, and contribute to a more sustainable food system. It is principally remarkable that pulses have a very low water foot-mark compared with other protein sources, and it can be grown in very poor soils, where other crops cannot be cultivated. Their crop residues along with other legumes in general, can also be used as animal fodder, thus, increasing the quality of the animal diet. Moreover, they can play a critical role in climate change adaptation, as they deliver an immense genetic diversity from which climate-resilient varieties can be selected and/or bred (FAO, 2016). They also contributed significantly to Ethiopians balance of payments by being the third most export food grain, next to coffee and sesame (Yirga et al., 2010; Koroma et al., 2016; Getachew, 2019; Kebede, 2019).

Accordingly, grain legumes, including pulses account for about $13 \%$ of cultivated land and are critical to smallholder income, food source and animal feed in Ethiopia (CSA, 2015; Keneni et al., 2018; Kebede, 2019). They are among the most important crops produced across the country next to cereals (Atnaf et al., 215). Twelve species of legumes have been indicted to be grown in the country. Among these legumes, grass pea (Lathyrus sativus L.), fenu greek (Trigonella foenum-graecum L.), lupine (Lupinus albus L.), chickpea (Cicer arietinum L.), faba bean (Vicia faba L.), lentil (Lens cultinaris Medik.) and field pea (Pisum sativum L.) have been cultivated in the cooler highlands and considered to be highland legumes. Conversely, cowpea (Vigna unguiculata L.), pigeon pea (Cajanus cajan L.), haricot bean (Phaseolus vulgaris L.), soya bean (Glycine max L.) and mung beans have been grown in warmer areas, and regarded as low land legumes of the country (Yirga et al., 2010; CSA, 2018; Getachew, 2019; Kebede, 2019).

Faba bean accounts for the greatest portion of production (36\%) among various legumes grown in Ethiopia, followed by haricot beans (17\%) and chickpeas (16\%), while other pulses (lentils, peas, lupines, and mung beans) account for the remaining 32\% (Yirga et al., 2010). The crop is being produced in most regions the country for food, income, and foreign currency, soil fertility restoration as tried to mention above (Bekele et al., 2018), and break residual pest infestation when rotated with cereals. It is a staple food used in different forms by the majority of small-scale subsistence farmers in the country alleviating malnutrition, and hence substitutes an expensive animal product like meat when consumed with cereals which are deficient in protein. It also plays an important role in the management of soil fertility through crop rotation in cereal production, hence contributing to agricultural sustainability (Keneni et al., 2018).

However, despite various significance of faba bean, in many developing countries, including Ethiopia, grain storage practices involve traditional structures, which are largely ineffective in the prevention of deterioration of stored products by post-harvest pests (Dubale et al., 2012; Hiruy, 2018). Deterioration of grains such as faba bean due to the infestations of pests such as insects, mites, rats, birds and fungi (molds) are the main post-harvest factor that has been affecting the nutritional quality and marketability (Dubale et al., 2012). Of these pests, storage insect pests are the major concerns for farmers worldwide, especially in developing countries like Ethiopia, because a large percentage of the crop may be lost due to them (Hiruy and Getu, 2018ab). The leading destructive storage pests of faba bean have been reported to be bruchids; Callosobruchus maculates (Fab.), C. chinensis (L.), Zabrotes subfasciatus (Boheman), and Acanthoscelides obtectus (Say) (Mesele et al., 2019).

Consequently, losses of food grains such as faba bean due to insect pests during storage has been reported to be one of the major causes of food insecurity of people living in the developing world, including Ethiopia (Hiruy, 2018). One way of reducing such huge loss and improvement of income and food security has been indicated to be recognition, promotion, and utilization of indigenous knowledge, skills, and practices of farmers that they developed in handling, processing, preservation, and storage of food grains (Okoye and Oni, 2017; Kuyu and Bereka, 2020). Therefore, prior to designing and implementation of any insect pest control intervention strategies, it is very vital to assess the status insect pest, degree of losses that have happened, indigenous methods and pest management practices used by the farmers during storage of their grains (Togola et al., 2013). This is because, assessing on these basic aspects by involving farmers (who are the immediate victims of the problem) provide baseline information that leads to identifying the existing problem under the farmers' storage condition of food grains, including faba bean. Consequently, this assessment might aid in designing and implementation of effective, affordable, and safe management strategies that could be easily adopted by farmers (Hiruy and Getu, 2018a; Hiruy, 2018). Accordingly, the current study assessed various farmers' management practices of insect pests of stored faba bean in the Farta District of South Gonder Zone of North West Ethiopia.

\section{Materials and methods}

\section{Description of The Study Area}

Farta district is located in the south Gonder zone of the Amhara Regional State (ARS). It lies between 110 32' to 120 03' latitude and 370 31' to 380 43' longitude (SPEDD, 2001; Araya, 2015). It is one of the 105 districts in the Amhara Regional State of Ethiopia, bordering Debre-Tabor, the capital of South Gondar Zone. It is located at about 100 $\mathrm{km}$ northeast of Bahir Dar, the capital of the Amhara Region and at about $666 \mathrm{~km}$ from Addis Ababa, the capital of Ethiopia. It lies within an altitude range of 1920-4135 m above sea level (Figure 1) (Ferede et al., 2014).

The average annual minimum, maximum, and mean temperatures are $9.540 \mathrm{C}, 22.11^{\circ} \mathrm{C}$ and $15.8^{\circ} \mathrm{C}$, respectively. The pattern of rainfall in the district is unimodal, stretching from May to September. Annual rainfall ranges between 1097 to $1954 \mathrm{~mm}$ with a long-term average of $1448 \mathrm{~mm}$ (Amsalu, 2010). Concerning land use pattern, an estimated $52.98 \%$ of the area is cultivated and planted with annual and perennial crops, while the area under grazing and browsing, forests and shrubs, settlements, and wastelands account for the 47.02\% (SPEDD, 2001; Araya, 
2015). In the district, agriculture contributes much in meeting major demands of farmers such as food supplies and cash needs, though, it is rain-fed and subsistence. The dominant crops grown in the district are barley, wheat, teff (Eragrostis tef (Zucc.) Trotter), sorghum, maize, field bean (faba bean), field pea, chickpea, millet, lentil, oil crops and root and tuber crops like potato (Araya, 2015). Despite the production of all these crops in the district, the major socioeconomic problem has been reported to be food insecurity (Ferede et al., 2014).

The Study Design, Period and Sampling Procedure

The survey was conducted in between 4 January 2019 - 15 May 2020 in six, major faba bean producing peasant associations (PAs) that had a relatively different agroclimatic condition of Farta woreda (district). The PAs were namely Abaregay (dega or high land), Weybila-Selamko, Kanat, Eyesus (weyna dega or mid latitude), Buro-kantona and Werkien (kolla or low land) (Figure 1).

From each PA, five villages were selected at random with the assistance of the Ministry of Agriculture (MOA) sub-kebele staff using a nested design as adopted by earlier researchers (Getu, 1993; Hiruy and Getu, 2018ab; Hiruy, 2018). From each village, four households were selected randomly and presented with semi-structured questionnaires and face to face interview. At each village, four households of a different age and gender were invited to the study of the participatory discussion and open-ended topics were raised to generate a free flow of ideas. Kebeles were selected purposefully based on the abundance of faba bean production, such that all kebeles growing faba bean most were selected for the survey, while villages and representative farmers were selected randomly. Prior to data collection or questionnaire filling, enumerators were employed and hands-on training was given to both farmers/households, and the extension workers on the objective of the study, proper filling of the questionnaires, and data collections as adopted by previous researchers (Getu, 1993; Tadesse, 1996; Hiruy and Getu, 2018ab).

Then, data was gathered on the status of insect pests relative to other pests, and the type and status of pest management practices, harvesting period as well as storage methods used by the farmers. Data were also collected on perception and preferences of the different practices used by the farmers to protect their faba grain during the storage periods in the study area. Furthermore, data was gathered about the form of the faba bean stored, periods and purposes of storage of faba beans, among others. Colored pictures of insect pests (bruchids) from books of stored product insects (Rees, 2004; 2007; Hagstrum et al., 2013) were presented to respondent farmers to help them in identifying pests of stored faba bean.

\section{Data Analysis}

The data collected from the survey were summarized, managed and analyzed using Microsoft excels software version 2010 and the Statistical Program for Social Sciences (SPSS) software version 2016. Descriptive statistics (frequency and percentage) were used for computing the data about the pest type, harvesting period, storage methods used, form of faba bean stored, management practices used and their efficacy as well as periods and purposes of storage of faba beans, among others.

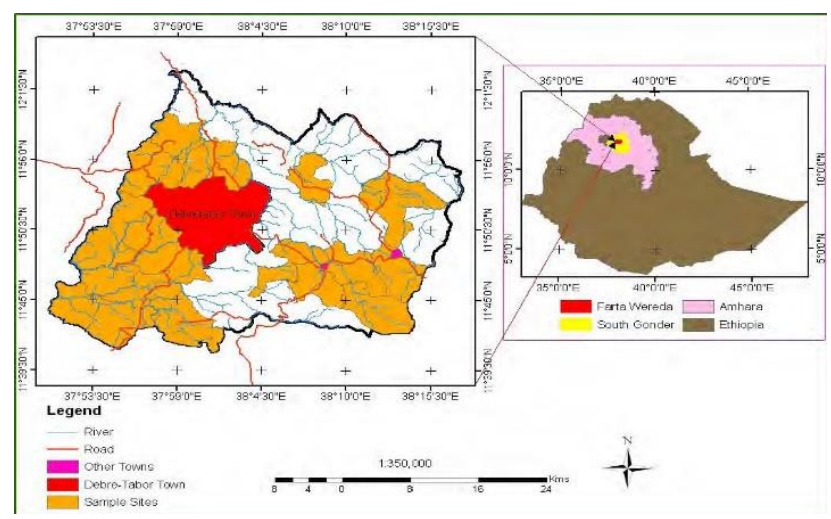

Figure 1. Map of the study area; Source: Amsalu (2010)

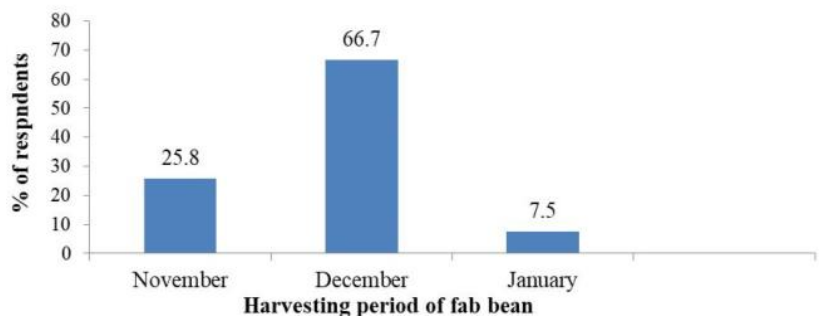

Figure 2. Harvesting period of faba bean in the study area

\section{Results}

Faba Bean Harvesting Time and Methods in Farta District

Harvesting period of faba bean by the farmers in the farta district is indicated in Figure 2. Accordingly, faba bean was harvested in between November and January for different reasons. Of the different harvesting period, the most commonly practiced harvesting period of faba bean was $(66.7 \%)$ indicated to be December, followed by $(25.8 \%)$ November in the survey sites according to respondents. However, January was less commonly used harvesting period faba bean $(7.5 \%)$ (Figure 2).

In another way saying, the majority of farmers harvested their faba bean grain in usual or optimum time (in December) fearing insect pests infestation in the field, and the subsequent damage in storage that they previously experienced. However, some farmers harvested their faba bean earlier, in November because of fearing of losses due to animal, theft, and unexpected rain, and before the grains, and their pods are sufficiently dried. Besides, only a few farmers harvested their faba bean January (later than optimum time) due to of lack of money and labor to harvest and handle the harvested crop in the appropriate period.

Harvesting of faba bean was done more commonly by cutting the whole part by sickle $(65 \%)$, followed by uprooting the whole plant part by hand $(23.3 \%)$ according to the surveyed farmers. However, using both sickle and hand as harvesting methods of faba bean was practiced by only a few $(11.7 \%)$ percentages of farmers in the study area. The harvested faba bean was collected and stacked around the threshing field or living house for some days or weeks to make it dry enough before threshing and/or storage in different traditional storages on the survey site (Figure 3). 


\section{Methods and Forms of Faba Bean Stored by Farmers in Farta District}

The major storage methods used to store faba bean in the study areas were Gota outdoor, polyethylene bags (sacs) in amalgamation with Gota in living house, and Gota in the living house (Figure 4). Of which, the greater proportion of $(63.3 \%)$ of the farmers stored their faba bean grains in Gota outdoors, followed by those stored (23.3\%) in Gota indoor according to the respondents. Nevertheless, polyethylene sacs in combination with Gota indoor were used only by few proportions $(13.4 \%)$ of farmers for storing faba bean grains in the study area (Figure 4).

Regarding the threshing method, farmers threshed their grain after the faba bean crop was dried enough to store in sacs or gota for short or long-term storage. Threshing was done most commonly by the livestock $(66.7 \%)$, followed by beating with sticks $(25 \%)$. But, threshing faba bean through a combination of both livestock and beating with sticks was less commonly used $(8.3 \%)$ by farmers in the study area according to survey farmers (Figure 5).

\section{Pests of Stored Faba Bean in Farta District}

Concerning pests of stored faba bean in the study area, a greater percentage $(53.3 \%)$ of the farmers mentioned insect pests as a major problem under traditional storage conditions. However, only $21.6 \%$ and $8.3 \%$ of the farmers stated rodent and mold, respectively, as the major pests of their grains. $16.6 \%$ of the farmers indicated a combination insect pest, molds and rodents as the most important pests of stored faba bean grains (Figure 6). Among insect pests, bruchid weevils (Callosobruchus species) were reported to be the most predominantly and frequently occurring insect pests on the stored faba bean grain.

\section{Storage Periods, Purpose, and Form of Storage of} Faba Bean in Farta District

The majority of (48.3\%) farmers the study area stored their faba bean grains begging from December to January for up to 6 to 12 months, depending on their different circumstances. However, low proportion of farmers (33.3 $\%$ ) stored their faba bean grain up to 2-5 months long, while relatively a few percent $(18.4 \%)$ farmers stored it up to one year long, and above in the survey sites (Figure 7).

Concerning purpose of storage faba bean grain, a high proportion of $(52.5 \%)$ farmers gave home consumption as the main purpose, while relatively low proportion $(38.3 \%)$ of them indicated a combination of home consumption and expecting better price as main purpose. Nonetheless, only a few $(9.2 \%)$ proportion of them said, expecting better price as the main purposes for storing their faba bean grain in the survey site (Figure 8).

Farmers in the study area stored their faba beans in different forms. $65 \%$ of the farmers stored their faba beans in seed (threshed) form, while $50 \%$ of them stored their beans in both threshed and un threshed form. But, only 5\% of the farmers stored faba beans in un threshed form alone (Table 1).

\section{The Level of Insect Pest Infestation of Faba Bean in Farta District}

The level of insect infestation in the study area, varied both with periods of storage and form of faba bean grain stored (Table 2 and Figure 9). According to the majority of
(>62\%) of farmers, the level of infestation was high, when their threshed faba bean stored for 3-6, 7-9 and 10-12 months in their traditional storage facilities (Table 2).

On the contrary, high level of infestation was occurring only when un-threshed faba bean was stored for more than 7 months, according to most (> $75 \%$ ) of farmers. Besides, $65.00 \%$ of the farmers indicated that a medium and low level of infestation was occurring, when un-threshed form of faba beans stored for 3-6 and 1-2 months (Figure 9). Consequently, storing un-threshed form of faba bean in Gota outdoor provided better protection for relatively longer period than storing it in the threshed form under the different storage methods.

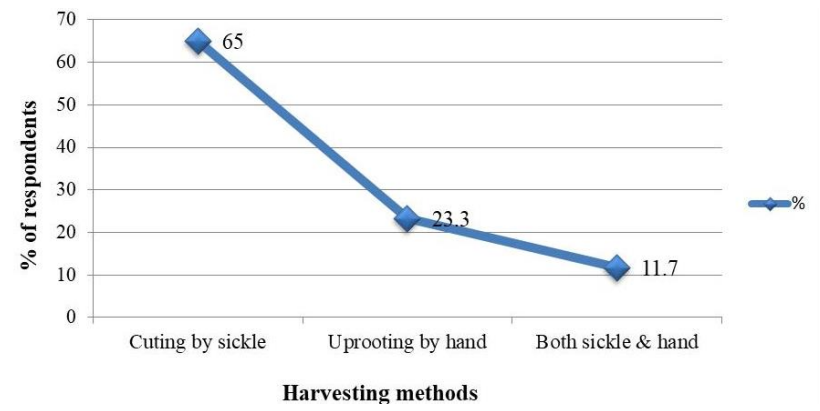

Figure 3. Harvesting methods of faba bean in the study area

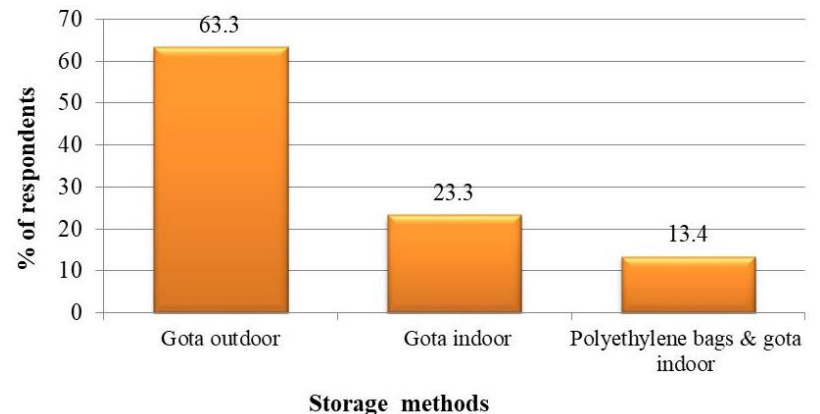

Figure 4. Farmers faba bean storage methods in the study areas

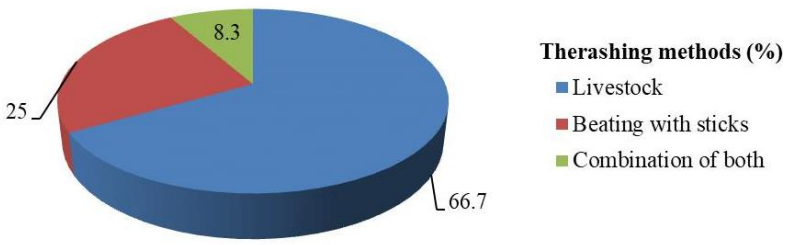

Figure 5. Farmers threshing method of faba bean in the study area

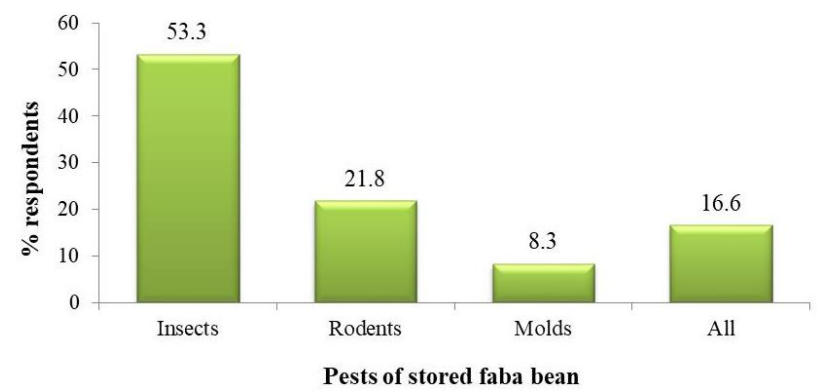

Figure 6. Pests of stored faba bean in the study area 
Table 1 . Forms of storage faba beans in the study area

\begin{tabular}{l|c}
\hline \multicolumn{1}{c|}{ Form of faba bean stored } & Percentage \\
\hline Threshed form & 65 \\
Threshed and un threshed form & 50 \\
Un threshed form & 5 \\
Total & 100 \\
\hline
\end{tabular}

Table 2. The level of insect infestation in different storage period in threshed form of faba bean in the study area

\begin{tabular}{l|ccc}
\hline Level of insect infestation & Months & Frequency & Percentage \\
\hline High & $3-6$ & 75 & 62.50 \\
High & $7-9$ & 84 & 70.00 \\
High & $10-12$ & 80 & 66.67 \\
\hline
\end{tabular}

Table 3. Farmers use of highly insect damaged faba bean grains in the study area

\begin{tabular}{l|cc}
\hline \multicolumn{1}{c|}{ Farmers use damaged faba bean } & Frequency & Percentages \\
\hline Animal feed & 42 & 35 \\
Spread on the ground for soil fertility & 35 & 29.17 \\
For seed purpose in the year of drought & 12 & 10 \\
Sold in a local market at reduced price & 31 & 25.83 \\
Total & 120 & 100 \\
\hline
\end{tabular}

Table 4. Extent of post-harvest loss of faba bean along the post-harvest chain in the study area

\begin{tabular}{l|ccc}
\hline \multicolumn{1}{c|}{ Postharvest loss } & Frequency & Percentage & Rank \\
\hline At the time of harvest & 25 & 20.83 & 2 \\
At the time of transportation & 10 & 8.33 & 5 \\
At the time of stacking & 15 & 12.5 & 4 \\
At the time of threshing & 20 & 16.67 & 3 \\
At the time of storage & 60 & 41.67 & 1 \\
\hline
\end{tabular}

Table 5. Farmers' insect pest management practices of stored faba bean in the study area

\begin{tabular}{l|cc}
\hline \multicolumn{1}{c|}{ Management Practices } & Frequency & Percentage \\
\hline Cultural methods & 15 & 12.5 \\
Botanicals & 25 & 20.83 \\
Chemical pesticides & 10 & 8.33 \\
Combination of cultural and botanical methods & 30 & 25 \\
No management measure & 40 & 33.33 \\
\hline
\end{tabular}

Table 6. The cultural methods used by the farmers in the study area

\begin{tabular}{l|ccccc}
\hline \multicolumn{1}{c|}{ Cultural methods } & Kolla & Dega & Weyna Dega & Mean frequency & Percent \\
\hline Mixture of animal dung and urine & 7 & 3 & 4.75 & 5.25 & 35 \\
Mixing faba bean grains with ash and sand & 5 & 2.8 & 3.09 & 3.63 & 24.2 \\
Mixing faba bean grains with small grains & 3 & 1.39 & 2 & 2.13 & 14.2 \\
Separating infested and exposing to sun & 3 & 1 & 1.22 & 1.74 & 11.6 \\
Other & 3 & 1.7 & 2.05 & 2.25 & 15 \\
\hline
\end{tabular}

Farmers Use of Highly Damaged Faba Bean Grains Due to Insect Pests in Farta District

Major proportion $42(35 \%)$ and $35(29.17 \%)$ of the farmers used highly perforated faba bean grains by insect pests for animal feed and for improving soil fertility (by spreading them on the farm), respectively. But, some percentage $31(25.83 \%)$ of the farmers sold highly insect damaged faba bean in a local market at a reduced price (Table 3 ).

Extent of Post-Harvest Loss of Faba Bean Along the Post-Harvest Chain in Farta District

Farmers reported that post-harvest losses of faba bean was occurring beginning from the time of harvesting to the consumption stage. According to them, the extent of loss may vary from farmers to farmers, depending on farmers' post-harvest practices. Accordingly, the majority of the farmers mentioned that post-harvest loss of faba bean occurred during storage $(60 ; 41.67 \%)$ period, followed by at harvesting $(25 ; 20.83 \%)$, threshing $(20 ; 16.67 \%)$ and stacking $(15 ; 12.5 \%)$ stages, respectively. However, less than ten percent of the farmers reported that post-harvest loss of faba bean was happening during the transportation stage of the post-harvest chain (Table 4).

\section{Farmers Management Practices of Stored Faba Bean} Insect Pests in Farta District

Farmers in the study area used different management practices to manage insect pests of stored faba bean. These include the use of synthetic chemical pesticides, the use of botanicals in different forms and cultural methods such as sun drying. Besides, farmers also practiced the application of mixture of animal dung and urine in different parts of storage facilities, and use no management measures (Table 5). 


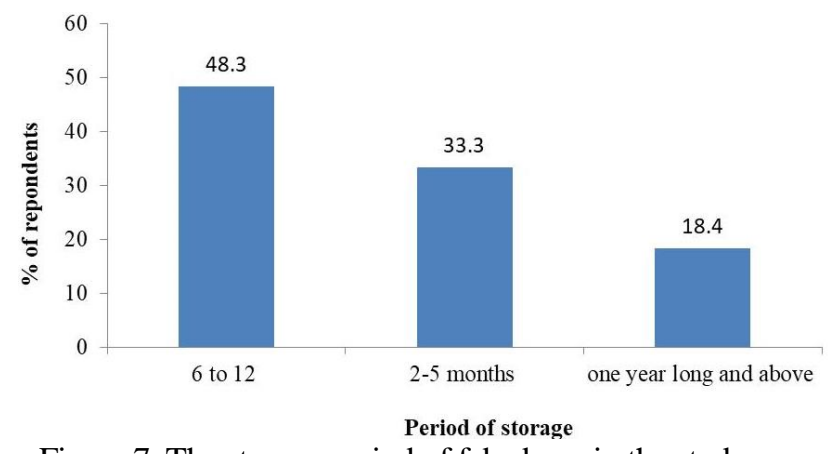

Figure 7. The storage period of faba bean in the study area

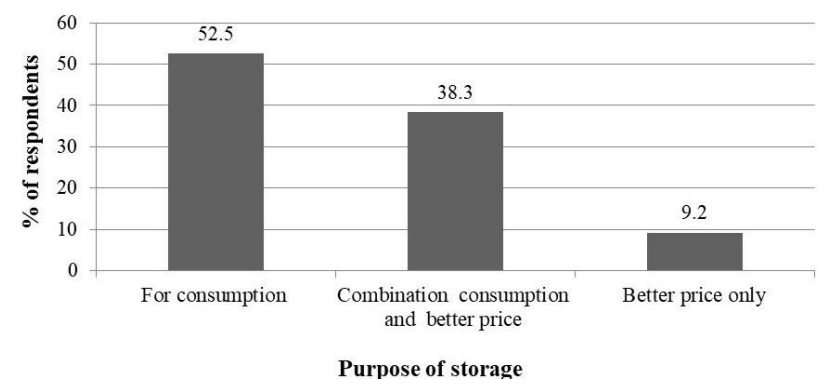

Figure 8 . The purposes of stored faba bean in the study area

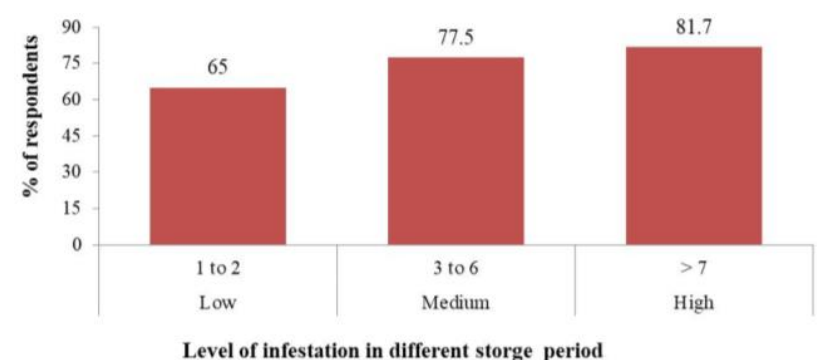

Figure 9. The level of insect infestation in different storage period in un threshed form of faba bean in the study area

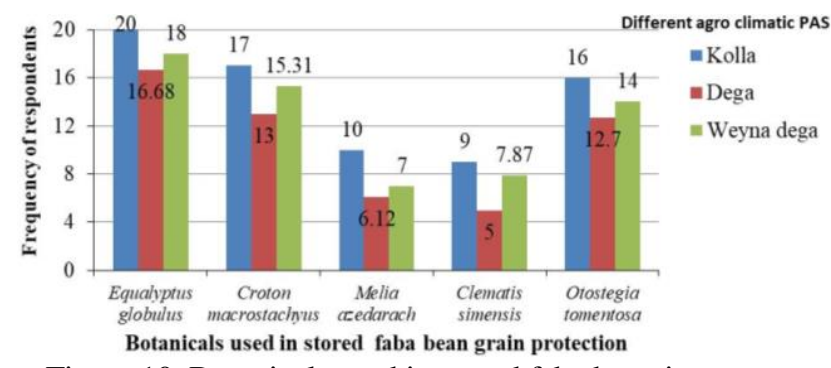

Figure 10. Botanicals used in stored faba bean insect pest management of the study area, PAs= peasant association

The majority $(40 ; 33.33 \%)$ of farmers use no pest management measures for reasons like high cost, lack access and knowledge and skill to use synthetic chemicals. Considerable proportion of the farmers $(30 ; 25 \%)$ used a combination of cultural and botanical methods. Besides, significant percentage of the $(25 ; 20.83 \%)$, and $(15 ; 12.5 \%)$ farmers used botanicals, and cultural methods to manage insect pests, respectively. However, few percentages (10; $8.33 \%)$ of them used synthetic chemical pesticides like Malathion 5\% dust for management of insect pests of stored faba bean (Table 5).

Among botanicals $(25 ; 20.83 \%)$ used for protection of stored faba beans in the study area, Eucalyptus globlus was preferred first $(18.32 ; 87.50 \%$ on average), followed by Croton macrostachyus $(15.10 ; 72.50 \%$ on average) and
Otostegia tomentosa (14.23; $68.33 \%$ on average). However, relatively the less preferred $(<7.8 ; 42 \%$ on average) botanicals were Clematis simensis and Melia azedarac (Figure 10).

Among those cultural methods $(15 ; 12.5 \%)$ used in the survey site, a greater percentage $(35 \%)$ of the respondents on average used a mixture of animal dung and urine, followed by those used $(24.2 \%)$ mixing the faba beans with ash and sand. However, less than $14.5 \%$ of farmers used mixing the faba beans with small grains like millet as well as separating infested faba bean grains and exposed them to sunlight for immediate consumption (Table 6).

\section{Discussion}

In the present study, harvesting of faba bean was done in between November and January, and the majority of farmers harvested their faba bean grain in usual or optimum time (in December) fearing of insect infestation in the field and subsequent damage in storage that they previously encountered. This finding indicates that farmers have good indigenous knowledge regarding the harvesting period in relation to pest infestation, and reduction of the loss of grains by the pests, and the associated food insecurity. Promotion of this knowledge through awareness creation by the experts could have paramount impacts in stored grains protection. Similarly, it was revealed that harvesting of faba bean should be done at the appropriate stages when the leaves, and the pods dry out and when the grain moisture content is significantly reduced (Keneni et al., 2001). It was also reported that as Ethiopian farmers commonly harvest most crops after physiological maturity is attained and when the moisture content reaches as low as $13 \%$ or below (Ashagari, 2000; Mohammed and Tadesse, 2018).

In the present study, the harvested faba bean was collected and stacked around the threshing field or living house for some days or weeks to make it dry enough before threshing and/or storage in different traditional storages on the survey site. This finding together with the above also indicates that farmers are wealth in different homegrown knowledge in association with pest protection, the associated loss and food insecurity. Similarly, it was also revealed that one way of reducing huge loss by pest infestation and improvement of income and food security is recognition, promotion, and utilization of indigenous knowledge, skills, and practices of farmers that they developed in handling, processing, preservation, and storage of food grains (Kuyu and Bereka, 2020). Proper drying of food grains prior to storage was also reported to be one of the cultural control methods in which farmers in Ethiopia has been using to control pest infestation by reducing moisture content (Getu, 1993; Kuyu and Bereka, 2020). Mohammed and Tadesse (2018) also revealed that most farmers in Ethiopia were well acquainted with the fact that further drying after harvesting is very important for both successful threshing, and good storage without mold and insect development.

Farmers used different storage methods (facilities) and stored their faba bean either threshed or threshed in the present study. Similarly, it was revealed that farmers in the different parts of Ethiopia has been using different traditional storage facilities (indoor or outdoor; gotera, 
gotta, keffo, barrels, and underground pits among others) to store their grain in different forms (Tadesse, 2008; Mohammed and Tadesse, 2018). Bachewe et al. (2019) and Dubale (2014) also reported as different type of traditional storage structures were used to store different types of grains in various parts of Ethiopia.

Being the most commonly used storage method of outdoor Gota by farmers for storing their faba bean grains in the current study might probably be related its better protection, as it was ventilated in outdoors than the rest of the storages avoid it as is redendency. Awareness creation and encouragement of farmers to use outdoor Gota, among other promising practices mentioned above, therefore, is very imperative in connection with reduction of stored grain loss by the pests, and the associated food insecurity. Nukenine (2010) also reported that different factors such as the type of storage structures used, the duration of storage and the storage management implemented prior to, and during storage could influence storage losses. It was also indicated that subsistence farmers in developing countries rely on traditional storage structures, which are vulnerable to bruchid attack, with some exceptions like gota and gotera outdoor (Dubale, 2014; Yemane, 2013).

Threshing was done most commonly by the livestock, followed by beating with sticks both of which might lead to significant damage to the grain. This damage could in turn lead to rapid pest infestation and mold development that could heighten further loss and the resultant food insecurity. This calls for enhancement of traditional threshing methods by concerned body. Similarly, it was reported that most of the traditional threshing practices (beating with sticks, animal trampling, and a combination of both) cause much loss to the grains quality via the scattering of grains out of the threshing floor and contamination with the waste of trampling animals (Mohammed and Tadesse, 2018). Hiruy (2018) was also reported that poor grains handling practices during harvesting and threshing, among others, are responsible for increasing pests' proliferation, especially secondary pests during storage, as they could have led to grains mechanical damage that could favor secondary pests.

In accordance with various purposes' storage mentioned by farmers in the present study, it was also shown that farmers stored bean seeds for different purposes such as for home consumption, as a source of seed for next planting, and to speculate the selling price (Jones, 1999; Chakraverty et al., 2003; Utono et al., 2013, Hiruy, 2018). In spite of the intended purposes of storage by the farmers, the stored faba bean grains were used commonly for animal feeds and for improving soil fertility due to series attack of pests after 3 and 7 months storage period both in threshed and un threshed forms, respectively in the current study. This is an implication for presence of great loss of the faba bean grain to which farmers have invested their knowledge, energy and money due to pests and as the impact of pests be significant under traditional food grain storage of the study area. This also suggests the presence of a need of improvement of the existing farmers' storages to preserve food grains for longer period with minimal loss and food insecurity problem. Similarly, Mboya (2011) also shown that traditional storage methods reduced stability, promoted vulnerability to pest attack and increased food insecurity of the farm households. Consistently, farmers' traditional storage structures were revealed to be poorly built and do not provide sufficient protection to the stored grains from pests, in developing nations, including Africa (Manandhar et al., 2018).

Being the major problem of insect pests in the stored faba bean of the different pests under traditional storage conditions in the present study, is in accordance with findings of pervious researchers (Tadesse, 2008; Dubale, 2014; Hiruy, 2018), in which insects were reported to be responsible for the major grain losses in Ethiopia. This suggests the presence need to give greater emphasis for management of stored grain insect pests with among others, to reduce grains loss and the associated food insecurity of farmers. It also calls for the improvement of the existing farmers' pest management practices of the study area, to achieve better grains' protection against insects, and improve farmers' food and income security.

The majority of farmers stored their faba bean grain for about 6-12 months starting from December to January in the present study, which is in accordance with the finding of previous scientists (Utono et al., 2013; Nukenine, 2010). Similar surveys in Rwanda also showed that $63.8 \%$ of the farmers stored common bean for 6 to 12 months (Umubyeyi and Rukazambuga, 2016).

In the present survey, in spite of the different traditional practices used by the farmers to protect their grains, the level of insect pests infestations were found to be high both in the threshed and un-threshed form of Faba bean stored in about 3-12 and >7 months storage period, respectively. This suggests the existence of significant loss of stored faba bean and the associated food insecurity problem in the study area, for which farmers were invested time, knowledge, energy and money. Accordingly, earlier researchers (Nukenine, 2010; Kasozi, 2013) have also shown that as the level of insect pests infestation increased with increased times of storage stored faba beans. This high insect infestation level might be probably because, when grains are stored for a long period, the respiration by the insects and molds within the grain, and the grain itself elevates the carbon dioxide, relative humidity and temperature levels in the storage environment, which could in turn favor further pests' development (Christensen and Kaufmann, 1965; Hiruy, 2018).

In accordance to the result of the current study regarding grain losses at different post-harvest stages, the maximum losses have been reported to be occurring during storage on the post-harvest system in Ethiopia (Mohammed and Tadesse, 2018).

Most farmers in a current study perceived that insecticides were expensive, less accessible and not easy to use, and hence, they did not prefer to use them. This might probably be due to different reasons such as a knowledge gap regarding wise use, and choice of selective insecticides. Similarly, it was revealed that most farmers in developing countries generally lack knowledge in the handling, and application of chemical insecticides (Atreya et al., 2011), which might cause health and environmental effects (Manandhar et al., 2018). This suggests the existence of the need to offer training for farmers on the safe use and choose of selective insecticides with minimal effect on non target organisms health and environment.

Among the pesticidal botanicals, Eucalyptus globlus was preferred first, followed by Croton macrostachyus and Otostegia tomentosa in the present study. These variations 
in preference pesticidal plants by the farmers could probably be due to their variation in their efficacy against insect pests of stored faba bean. This finding suggests the presence of potency of the aforementioned three botanicals in protection of insect pests of stored faba bean and their loss as well as food insecurity of poor farmers. Similarly, pesticidal plants and other traditional pest management practices, which are eco-friendly, economical, and usually target specific and most are essentially nontoxic to animals and humans, have been suggested for use in storage pest management (Kamanula et al., 2010; Stevenson et al., 2017). Yemane (2013) also reported as various botanical insecticides were preferred by farmers, since they were effective against oviposition and emergence of adult bruchids. Olayemi et al. (2012) also demonstrated that application of botanicals were promising and effective to manage bruchid insects.

Following the use of no management measures, considerable percent of the farmers used a combination of cultural and botanical methods to manage insect pests of stored faba bean. A significant percentage of farmers also used botanicals to protect their stored faba bean from insect pests in the present survey. This suggests that these traditional practices were promising pest management options for protection of stored faba bean. Thus, improving the effectiveness these practices by integrating with other safe and effective practices (for example, by integrating with outdoor ventilated Gota and use of resistant varieties) and promoting them might have significant impact in stored faba grains protection from pests. This in turn reduces the grain loss by the insects, and the associated food insecurity of the study area, in particular and Ethiopia, in general. Accordingly, it was also revealed that a little improvement in storage structures coupled with sound hygienic measures and other cultural practices can lead to significant reduction in storage loss of grains (Tadesse, 2003). Similarly, it was reported that improvements to the main storage structure used by the farmers and using locally available plant materials and cultural methods instead of chemicals could help to improve farmers' food security (Utono, 2013). It was reported that smallholder farmers in Africa have been using different traditional practices which include the use of various pesticidal plants and wood ashes among others, for the control of storage pests (Kamanula et al., 2010).

\section{Conclusion and Recommendation}

In the current study it was possible to recognize that farmers had worthy indigenous knowledge concerning different cultural practices. That means farmers had good indigenous knowledge regarding harvesting period, sufficient grain drying and the use of outdoor ventilated gota and botanicals, among others in relation to reduction of pest infestation. Besides, Eucalyptus globlus, Croton macrostachyus and Otostegia tomentosa, respectively, were the three most botanicals preferred and are used by the farmers in the study area and thus, suggested being potent. Thus, improving the effectiveness of these practices in an integrated fashion, for example, integrating the outdoors ventilated gota with the use of resistant varieties, and the aforementioned potent botanicals is very imperative. This, in turn, could be very vital in promoting these promising indigenous practices and might have a significant impact on stored faba bean grains protection and the associated food insecurity of poor farmers of the study area, in particular, and Ethiopia, in general. Consequently, there is a need of improvement and promotion of such promising traditional practices of farmers by concerned bodies to achieve better protection of their grain from insect pests and improvement of income and food insecurity.

Furthermore, the most commonly used threshing methods of faba bean (using livestock, followed by beating with sticks) were suggested to cause significant damage to the grain in the current study. This damage could in turn lead to rapid pest infestation and mold development that could heighten further loss of the grain during storage. Therefore, alternative threshing methods that reduce damage to the grain should be designed and introduced to the farmers of the study area by the concerned body.

In the present study, it was also possible to notice that the stored faba bean was attacked by different pests, especially bruchid weevils, i.e. Callosobruchus species were reported to be the major problem according to the respondent Farmers. Besides, in spite of the different traditional practices used by the farmers to protect their grains from pests, the level of insects infestations were found to be high in threshed and un threshed form of faba bean stored after 3 and 7 months storage periods, respectively. Moreover, the stored faba bean were used commonly for different purposes such as for animal feeds and improving soil fertility than the primary planned goals of storing it by farmers, due to series attack pests after extended storage period. Accordingly, presence of considerable loss of the faba bean grain due to pests, and the associated food insecurity problem to which farmers have invested their knowledge, energy, time and money was also suggested in the study area.

As a result, the farmers' traditional practices were ineffectual for reasonable safeguard of stored faba bean from insect pests for elongated storage period and the associated food insecurity. Thus, planning effective stored faba bean pests management strategies in the study area is needed. In addition, improving the existing farmers' traditional storage structures and other non-promising traditional practices is required. Moreover, delivery of training to farmers and extension workers on safe management of insect pests of stored faba bean under farmers' traditional storage conditions is desirable.

\section{Acknowledgments}

We authors honestly thank Dr. Ofgaa Djirata, Dr. Fekadu Massebo, and Dr. Serekebirhan Takele for the comments and suggestions in the overall component of earlier version of this article as a part of the first author MSc thesis, by being external and internal reviewers, respectively. We would also like thank the School of Graduate Studies of the Collage of Natural Sciences of the Arba Minch University for financial support to conduct this study.

\section{References}

Amsalu N. 2010. An ethno botanical study of medicinal plants in Farta Wereda, South Gondar, Amhara Region, Ethiopia. MSc Thesis, Collage of Natural and Computational sciences, Addis Ababa University, Addis Ababa, Ethiopia. 
Araya AK. 2015. Evaluation of barley varieties against Russian wheat aphid (Diuraphis noxia M.) under greenhouse condition. Journal of Agriculture and Environmental Sciences, 1(1): 2636-3713.

Ashagari D. 2000. The concept of post-harvest loss and its application in Ethiopia. pp. 1-11, In: EARO. Post-harvest and storage technologies research and extension. In Proceedings of a conference organized from June (Vol. 6). Addis Ababa, Ethiopia.

Atnaf M, Tesfaye K, Dagne K. 2015. The importance of legumes in the Ethiopian farming system and overall economy: An overview. Journal of Experimental Agriculture International, 7(6): 347-358, DOI: https: //doi.org/10.9734/AJEA/ 2015/11253.

Atreya K, Sitaula BK, Johnsen FH, Bajracharya RM. 2011. Continuing issues in the limitations of pesticide use in developing countries. Journal of Agricultural and Environmental Ethics, 24(1): 49-62, DOI: https://doi.org/ 10.1007/s10806-010-9243-9.

Bachewe F, Minten B, Seyoum TA, Pauw K, Cameron A, Genye ET. 2019. Farmers' grain storage and losses in Ethiopia. Journal of Agricultural and Food Industrial Organization, 18(1), DOI: https: //doi.org/10.1515/jafio-2019-005.

Bekele B, Dawit W, Kassa B, Selvaraj T. 2018. Management of faba bean gall disease using cultivars and fungicides in North Showa Zone of Central Ethiopia. International Journal of Research in Agricultural Sciences, 5 (1): 2348-3997.

Chakraverty A, Mujumdar AS, Ramaswamy HS, editors. 2003. Handbook of postharvest technology: cereals, fruits, vegetables, tea, and spices (Vol. 93). CRC press. pp. 907.

Christensen CM, Kaufmann HH. 1965. Deterioration of stored grains by fungi. Annual Review of Phytopathology, 3(1): 6984, DOI: https: //doi.org/10.1146/annurev.py.03.090165. 000441

CSA (Central Statistical Agency), 2015. Federal democratic republic of Ethiopia. Agricultural sample survey 2014/2015 (2007 E.C.). Addis Ababa, Ethiopia.

CSA (Central Statistical Agency). 2018. Agricultural sample survey, area and production of major crops (Private Peasant Holdings, Meher Season). Addis Ababa, Ethiopia.

Dubale B, Waktole S, Solomon A, Geremew B, Sethu MR. 2012. Influence of agro-ecologies, traditional storage containers and major insect pests on stored maize (Zea mays L.) in selected woredas of Jimma zone. Asian Journal of Plant Sciences, 11(5): 226-234, DOI: https: //doi.org/10.3923/ ajps.2012.226.234.'

Dubale B. 2014. Factors affecting quality of grain stored in Ethiopian traditional storage structures and opportunities for improvement. International Journal of Sciences: Basic and Applied Research, 18(1): 235-257, DOI: https://doi.gssrr.org/ index.php?journal.

FAO, 2016. Soils and pulses: symbiosis for life. Food and Agriculture Organization of the United Nations, Rome. Available from: http://www.fao.org/3/a-i6437e.pdf. [Accessed 8 December 2020]

Getachew T. 2019. Pulse crops production opportunities, challenges and its value chain in Ethiopia: A review article. Journal of Environment and Earth Science, 9: 1, DOI: https://doi.org/10.7176/JEES/9-1-03.

Getu E. 1993. Studies on the distribution and control of Angoumois grain moth, Sitotroga cerealella (Oliver) (Lepidoptera: Gelchidae) in Sidama Administrative Region. MSc Thesis,Alemaya University of Agriculture, Alemaya, Ethiopia.

Hagstrum D, Klejdysz T, Subramanyam B, Nawrot J. 2013. Atlas of stored-product insects and mites. AACC International. Inc. USA, St. Paul, Minnesota.

Hagstrum DW, Subramanyam B. 2006. Fundamentals of storedproduct entomology. AACC International. Inc (AACC), USA.
Hiruy B, Getu E. 2018a. Insect pest's infestation and the associated loss in stored maize grains in four farmers' traditional storage in southern Ethiopia. International Journal of Modern Chemistry and Applied Science, 5(1): 571-576.

Hiruy B, Getu E. 2018b. Screening of some maize varieties for resistance against the maize weevils, Sitophilus zeamais (Motsch.). International Journal of Entomology and Nematology, 4(1): 77-84.

Hiruy B, Getu E. 2018c. Efficacy of two locally available inert dusts against Sitophilus zeamais (Motschulsky) (Coleoptera: Curculionidae) of stored maize in Ethiopia, Journal of Stored Products and Postharvest Research, 9 (1): 1-7, DOI: https://doi.org/10.5897/JSPPR2018.0250.

Hiruy B. 2018. Status, species composition and management of stored maize grain insect pests in Southern Ethiopia. PhD Dissertation. Graduate Studies of College of Natural and Computational Sciences of Addis Ababa University Addis Ababa, Ethiopia.

Jones AL. 1999. Phaseolus bean: post-harvest operations. Postharvest compendium. Food and Agriculture Organization of the United Nations: Rome.

Kamanula J, Sileshi GW, Belmain SR, Sola P, Mvumi BM, Nyirenda GK, Nyirenda SP, Stevenson PC. 2010. Farmers' insect pest management practices and pesticidal plant use in the protection of stored maize and beans in Southern Africa. International Journal of Pest Management, 57(1): 41-49, DOI: https://doi.org/10.1080/09670874.2010.522264.

Kasozi LC. 2013. Genetic analysis and selection for maize weevil resistance in maize. PhD Dissertation. University of KwaZulu Natal, Pietermaritzburg, South Africa.

Kebede ME. 2019. Extent and management strategies of faba bean gall disease (Olpidium viciae Kusano) in Ethiopia: a review. EC Agriculture, 5.11: 13-24. doi: 10.4172/23298863.1000440

Keneni G, Fessehaie R, Gorfu D, Asmamaw B. 2001. A guide for faba bean and field pea seed producers. pp. 35. Available from: http://197.156.72.153:8080/xmlui/handle/123456789/3183

Keneni G, Mussa Jarso AT, Temesgen T. 2018. Progresses of faba bean (Vicia faba L.) and field pea (Pisum sativum L.) breeding and genetics research in Ethiopia. Ethiopian Journal of Crop Science. 6 (3).

Koroma S, Molina PB, Woolfrey S, Rampa F, You N. 2016. Promoting regional trade in pulses in the Horn of Africa. Accra, Ghana, FAO. Available from: http:www.fao.org.

Kuyu CG, Bereka TY. 2020. Review on contribution of indigenous food preparation and preservation techniques to attainment of food security in Ethiopian. Food Science and Nutrition, 8, 3-15, DOI: https: //doi.org/10.1002/fsn3.1274.

Manandhar A, Milindi P, Shah A. 2018. An overview of the postharvest grain storage practices of smallholder farmers in developing countries. Agriculture, 8(4): 57, DOI: https://doi.org/10.3390/agriculture8040057.

Marinangeli CP, Curran J, Barr SI, Slavin J, Puri S, Swaminathan S, Tapsell L, Patterson CA. 2017. Enhancing nutrition with pulses: defining a recommended serving size for adults. Nutrition reviews, 75(12), 990-1006, DOI: https: //doi.org/10.1093/nutrit/nux058.

Mboya R. 2011. A study of the effects of storage methods on the quality of maize and household food security in Rungwe District, Tanzania. PhD Dissertation. University of Kwazulu - Natal, Tanzania.

Mesele T, Dibaba K, Mendesil E. 2019. Farmers' perceptions of mexican bean weevil, Zabrotes subfasciatus (Boheman), and pest management practices in Southern Ethiopia. Advances in Agriculture, 2019(1): 1-10. https://doi.org/10.1155/2019/ 8193818.

Mohammed A, Tadesse A. 2018. Review of major grains postharvest losses in Ethiopia and customization of a loss assessment methodology. USAID/Ethiopia Agriculture Knowledge, Learning, Documentation and Policy Project, Addis Ababa. 
Nukenine EN. 2010. Stored product protection in Africa: past, present and future. Julius-Kühn-Archive, 425, 26. Available from: http://www.researchgate.net/profile/E_Nukenine/publication /277804734.pdf

Okoye JI, Oni K. 2017. Promotion of indigenous food preservation and processing knowledge and the challenge of food security in Africa. Journal of Food Security, 5(3): 75-87, DOI: https://doi.org/10.12691/jfs-5-3-3.

Olayemi FF, Adegbola JA, Bamishaiye EI, Awagu EF. 2012. Assessment of post-harvest losses of some selected crops in eight local government areas of rivers state, Nigeria. Asian Journal of Rural Development, 2(1): 13-23, DOI: https://doi.org/10.3923/ajrd.2012.13.23.

Rees D. 2004. Insects of stored products. Csiro Publishing

Singh N. 2017. Pulses: an overview. Journal of Food Science and Technology, 54(4): 853-857, DOI: https://doi.org/10.1007/ s13197-017-2537-4.

SPEDD (South Gondar Planning and Economic Development Department), 2001. South Gondar Administrative Zone Planning and Economic Development Department's annual statistical abstract. Debre Tabor, Ethiopia.

Stevenson PC, Isman MB, Belmain SR. 2017. Pesticidal plants in Africa: a global vision of new biological control products from local uses. Industrial Crops and Products, 110, 2-9, DOI: https://doi.org/10.1016/j.indcrop.2017.08.034034.

Szczebyło A, Rejman K, Halicka E, Laskowski W. 2020 Towards more sustainable diets-attitudes, opportunities and barriers to fostering pulse consumption in Polish Cities. Nutrients, 12(6): 1589, DOI: https://doi.org/10.3390/ nu12061589.
Tadesse A. 2008. Increasing crop production through improved plant protection - volume I (edition). Plant Protection Society of Ethiopia (PPSE), 19 - 22 December 2006. Addis Ababa, Ethiopia, PPSE and EIAR, Addis Ababa, Ethiopia. pp. 598.

Tadesse A. 1996. Insects and other arthropods recorded from stored maize in western Ethiopia. African Crop Science Journal, 4(3): 339-343.

Tadesse A. 2003. Studies on some non-chemical insect pest management options on farm stored maize in Ethiopia. $\mathrm{PhD}$ Dissertation. Giessen University, Germany.

Togola A, Seck PA, Glitho IA, Diagne A, Adda C, Toure A, Nwilene FE. 2013. Economic losses from insect pest infestation on rice stored on-farm in Benin. Journal of Applied Sciences, 13(2): 278-285, DOI: https://doi.org/10.3923/jas.2013.278.285.

Umubyeyi S, Rukazambuga ND. 2016. Small scale farmers' knowledge on grain losses from bean bruchid, pesticides safe use and implication on food security and safety in Huye District, Rwanda. Rwanda Journal, 1(1S), DOI: https://doi.org/10.4314/rj.v1i2S.13D.

Utono IM. 2013. Assessment of grain loss due to insect pest during storage for small-scale farmers of Kebbi. IOSR Journal of Agriculture and Veterinary Science, 3(5): 38-50.

Yemane T. 2013. Bio rational control methods for protection of stored grain legumes against bruchid beetles. Agricultural Sciences, $4(12)$ : 762-766, https://dx.doi.org/10.4236/as.2013.412104.

Yirga C, Rashid S, Behute B, Lemma S. 2010. Pulses value chain potential in Ethiopia: Constraints and opportunities for enhancing exports. International Food Policy Research Institute, 3: 1-53, DOI: https://doi:10.13140/RG.2.1. 3968.0722 . 